\title{
MODEL SUSCEPTIBLE VACCINATED INFECTED TREATMENT RECOVERED DENGAN KASUS KAMBUH DAN PENERAPANNYA (KASUS TUBERKULOSIS DI INDONESIA)
}

\section{Susceptible Vaccinated Infected Treatment Recovered Model with Relapse and its Application (Tuberculosis Cases in Indonesia)}

\author{
Arifah Mufidah Lestari ${ }^{1 *}$, Purnami Widyaningsih ${ }^{2}$, Sutanto $^{3}$ \\ 1,2,3 Program Studi Matematika, Fakultas Matematika dan Ilmu Pengetahuan Alam, Universitas Sebelas Maret \\ Jl. Ir. Sutami No 36 A Kentingan, Surakarta, 57126, Indonesia \\ Corresponding author e-mail: ${ }^{1 *}$ arifah.mufidah@student.uns.ac.id
}

\begin{abstract}
Abstrak
Tuberkulosis (TB) disebabkan oleh Mycobacterium tuberculosis. Upaya preventif penyebaran TB di Indonesia, dilakukan melalui vaksinasi BCG. Individu yang divaksinasi (vaccinated) adalah individu sehat dan rentan terinfeksi penyakit (susceptible). Jika seseorang terinfeksi TB (infected) maka upaya kuratif melalui pengobatan DOTS (treatment) harus dilakukan agar sembuh (recovered). Pada kasus TB, individu sembuh dimungkinkan kambuh. Model susceptible vaccinated infected treatment recovered (SVITR) dengan kasus kambuh mampu merepresentasikan penyebaran TB. Penelitian ini bertujuan membangun model SVITR dengan kasus kambuh, menerapkannya pada kasus TB di Indonesia menggunakan data tahun 2004-2019, dan menginterpretasikan hasil penerapan terhadap target bebas TB di Indonesia tahun 2050. Model tersebut berbentuk sistem persamaan diferensial nonlinear orde satu. Grafik pola penyebaran TB menunjukkan seluruh kelompok individu mengalami trend naik dan diprediksikan target bebas TB belum tercapai. Namun, jika cakupan vaksinasi BCG dan pengobatan DOTS ditingkatkan, kontak dengan penderita TB dikurangi, serta kasus kambuh diturunkan maka diprediksikan target bebas TB tercapai.
\end{abstract}

Kata Kunci : SVITR, kasus kambuh, tuberkulosis, vaksinasi, pengobatan, bebas tuberkulosis.

\begin{abstract}
Tuberculosis (TB) is caused by Mycobacterium tuberculosis. BCG vaccination is prevention the spread of TB in Indonesia. Individuals who are vaccinated (vaccinated) are healthy individuals and susceptible to infection. If a person is infected with TB then curative efforts through DOTS treatment must be carried out in order to recover. In the case of TB, recovered individuals may relapse. The susceptible vaccinated infected treatment recovered (SVITR) model with relapse cases is able to represent the spread of TB. This study aims to build the SVITR model with relapse, apply it to TB in Indonesia using data from 2004-2019, and interpret the results of implementing the TB-free target in Indonesia in 2050. The model is nonlinear first-order differential equations. The graph of the pattern of TB spread shows that all groups of individuals are experiencing an uptrend and it is predicted that the TB-free target has not been achieved. However, if the coverage of BCG vaccination and DOTS treatment is increased, contacts with $T B$ sufferers are reduced, and relapse cases are reduced, it is predicted that the TB-free target will be achieved.
\end{abstract}

Keywords: SVITR, relapse, tuberculosis, vaccination, treatment, free of tuberculosis.

Article info:

Submitted: $04^{\text {th }}$ July 2021

How to cite this article:

A. M. Lestari, P. Widyaningsih, and Sutanto, "MODEL SUSCEPTIBLE VACCINATED INFECTED TREATMENT RECOVERED DENGAN KASUS KAMBUH DAN PENERAPANNYA (KASUS TUBERKULOSIS DI INDONESIA)", BAREKENG: J. Il. Mat. \& Ter., vol. 15, no. 04, pp. 667-674, Dec. 2021.

This work is licensed under a Creative Commons Attribution-ShareAlike 4.0 International License. Copyright @ 2021 Arifah Mufidah Lestari, Purnami Widyaningsih, Sutanto 


\section{PENDAHULUAN}

Penyakit menular disebabkan oleh virus, bakteri, jamur, maupun parasit dan menular ke manusia. Penyebaran penyakit menular terjadi akibat dari kontak antara individu terinfeksi dengan individu rentan penyakit. Penyebarannya melalui droplet, kontak kulit, feses, darah, luka, maupun plasenta. Penyebaran penyakit menular dapat direpresentasikan dengan model matematika. Model susceptible infected recovered (SIR) dikonstruksikan oleh Hethcote [3] pada tahun 2000. Populasi pada model tersebut dikelompokkan menjadi tiga, yaitu kelompok individu sehat namun rentan terinfeksi penyakit $(S)$, kelompok individu terinfeksi penyakit dan mampu menularkan penyakitnya kepada individu $S(I)$, dan kelompok individu sembuh serta kebal terhadap penyakit $(R)$. Vaksinasi dilakukan sebagai upaya preventif penyebaran penyakit menular. Liu et al. [5] mengonstruksikan model susceptible vaccinated infected recovered (SVIR) pada tahun 2008. Individu $V$ pada model tersebut merupakan individu $S$ yang telah divaksinasi. Pada tahun 2015, Islam 4[] mengonstruksikan model SVIR dengan asumsi populasi tidak konstan, mempertimbangkan faktor migrasi, serta kematian karena penyakit.

Upaya kuratif penyakit menular dilakukan melalui berbagai metode pengobatan. Side dkk. [9] mengembangkan model SIR [3] menjadi model susceptible infected tratment recovered (SITR) pada tahun 2015. Pada penelitian tersebut, individu $I$ harus melakukan pengobatan untuk sembuh. Individu $I$ yang melakukan pengobatan dikategorikan ke dalam individu $T$. Fenomena kekambuhan dapat terjadi pada individu sembuh yang telah melewati fase pengobatan. Pada kasus kambuh, individu sembuh kembali menjadi individu terinfeksi [10].

Tuberkulosis (TB) merupakan penyakit menular yang disebabkan oleh Mycobacterium tuberculosis dan paling sering menyerang paru-paru. Gejala utama TB yaitu batuk berdahak selama dua minggu atau lebih. Penyebaran penyakit ini melalui droplet. Berdasarkan World Health Organization (WHO) [11], pada tahun 2019 Indonesia menempati posisi ketiga sebagai negara dengan jumlah kasus TB terbanyak di dunia (543874 kasus). Melalui Permenkes Nomor 67 Tahun 2016 tentang Penanggulangan TB, Indonesia menetapkan target bebas TB tahun 2050. Upaya preventif penyebaran TB dilakukan dengan vaksinasi BCG pada bayi usia 0-2 bulan. Vaksin BCG pada keadaan terbaiknya mampu mencegah infeksi TB selama 15 tahun [1]. Kemampuan dari vaksin yang tidak dapat bertahan seumur hidup berakibat tetap diperlukannya usaha penyembuhan melalui pengobatan bagi penderita TB [2].

Upaya kuratif berupa pengobatan dilakukan melalui strategi directly observed treatment shortcourse (DOTS). Pada tahun 2018, Ramadhan dkk. [8] memformulasikan model matematika penyebaran TB dengan strategi DOTS. Berdasarkan penelitian Ramadhan dkk. [8], jika nilai laju pengobatan individu TB menjalani pengobatan DOTS semakin besar maka populasi penderita TB semakin kecil. Prinsip pengobatan TB yaitu diberikan dalam bentuk paduan obat anti TB (OAT) yang tepat mengandung minimal empat macam obat, diberikan dalam dosis yang tepat, ditelan secara teratur dan diawasi langsung oleh pengawas menelan obat (PMO) sampai selesai pengobatan, pegobatan diberikan dalam dua tahap. yaitu pengawasan langsung oleh pengawas menelan obat (PMO). Tujuan pengobatan TB yaitu menyembuhkan pasien dan memperbaiki produktivits hidup, Penderita TB yang melakukan pengobatan sesuai dengan prinsip pengobatan akan sembuh, tetapi tetap berpeluang mengalami kekambuhan.

Model SVIR dengan kasus kambuh telah dikonstruksikan oleh Widyaningsih et al. [12] pada tahun 2019. Faktor pengobatan dipertimbangkan dalam model tersebut namun tidak dikategorikan dalam kelompok individu tertentu. Pada penelitian ini, dibangun model susceptible vaccinated infected treatment recovered (SVITR) dengan kasus kambuh. Berbeda dengan Widyaningsih et al. [12], di sini individu yang melakukan pengobatan dikategorikan sebagai individu T. Model SVITR dengan kasus kambuh diterapkan pada kasus TB di Indonesia untuk mengetahui pola penyebarannya. Hasil penerapannya dikaitkan dengan target bebas TB tahun 2050. Simulasi nilai parameter dilakukan untuk mengetahui langkah yang harus ditempuh agar target bebas TB tahun 2050 dapat tercapai.

\section{METODE PENELITIAN}

Penelitian ini dilakukan menggunakan metode penelitian studi literatur. Metode penelitian dibagi menjadi dua yaitu data penelitian dan langkah penelitian. 


\subsection{Data Penelitian}

Data yang digunakan dalam penelitian ini adalah data sekunder tahun 2004-2019 yang bersumber dari Pusat Data dan Informasi Kementerian Kesehatan RI [7], World Bank [13], dan WHO [11]. Data dari Pusat Data dan Informasi Kementerian Kesehatan RI [7] berupa banyaknya kasus TB, banyaknya individu yang divaksin BCG, banyaknya penderita TB yang melakukan pengobatan, dan banyaknya individu yang sembuh dari TB.. Data dari World Bank [13] berupa jumlah penduduk Indonesia, crude birth rate (CBR), dan crude death rate $(C D R)$. Data dari $W H O[11]$ berupa banyaknya kematian akibat TB serta banyaknya kasus baru dan kambuh TB di Indonesia.

\subsection{Langkah Penelitian}

Langkah yang dilakukan dalam penelitian ini yaitu mengidentifikasi karakteristik penyakit menular, mengubah dan menambah asumsi serta parameter model SIR sehingga diperoleh model SVITR dengan kasus kambuh, mengestimasi nilai parameter berdasarkan data tahun 2004-2017, menyubstitusikan estimasi nilai parameter pada model SVITR dengan kasus kambuh sehingga diperoleh model SVITR dengan kasus kambuh pada kasus TB di Indonesia, menentukan nilai awal model tersebut berdasarkan data tahun 2004, menentukan penyelesaian model tersebut menggunakan Runge-Kutta orde empat, mengukur keakuratan model menggunakan data tahun 2018 dan 2019, menginterpretasi model dengan target Indonesia bebas tuberkulosis tahun 2050, dan melakukan simulasi nilai parameter.

\section{HASIL DAN PEMBAHASAN}

\subsection{Model $S I R$}

Pada model SIR yang dikonstruksikan oleh Hethcote [3], populasi diasumsikan konstan sebesar $N$ dan tidak mempertimbangkan faktor migrasi. Laju kelahiran dinotasikan dengan $\mu$ sehingga banyaknya kelahiran sebesar $\mu N$. Dengan demikian, individu $S$ bertambah sebesar $\mu N$. Sama dengan laju kelahiran, laju kematian dinotasikan dengan $\mu$ sehingga banyaknya kematian sebesar $\mu S, \mu I$, dan $\mu R$. Dengan demikian, individu $S$, $I$, dan $R$ berturut-turut berkurang sebesar $\mu S, \mu I$, dan $\mu R$. Individu $S$ dapat terinfeksi penyakit apabila melakukan kontak dengan individu $I$. Jika $\beta$ adalah laju kontak maka banyaknya individu $S$ yang terinfeksi sebesar $\beta \frac{S I}{N}$. Dengan demikian, individu $S$ berkurang sebesar $\beta \frac{S I}{N}$ dan individu $I$ bertambah sebesar $\beta \frac{S I}{N}$. Individu $I$ dapat sembuh dan diasumsikan memiliki kekebalan permanen. Jika $\gamma$ adalah laju kesembuhan maka banyaknya individu $I$ yang sembuh sebesar $\gamma I$. Dengan demikian, individu $I$ berkurang sebesar $\gamma I$ dan individu $R$ bertambah sebesar $\gamma I$. Model SIR oleh Hethcote [3] dituliskan sebagai

$$
\begin{aligned}
& \frac{d S}{d t}=\mu N-\beta \frac{S I}{N}-\mu S, \\
& \frac{d I}{d t}=\beta \frac{S I}{N}-\gamma I-\mu I, \\
& \frac{d R}{d t}=\gamma I-\mu R,
\end{aligned}
$$

dengan $S(0) \geq 0, I(0)>0, R(0) \geq 0$ dan $\mu, \beta, \gamma>0$. Parameter $\mu, \beta, \gamma$ berturut-turut adalah laju kelahiran/kematian, laju kontak, dan laju kesembuhan.

\subsection{Model SVITR dengan Kasus Kambuh}

Berbeda dengan asumsi model (1), pada penelitian ini diasumsikan populasi tidak konstan. Faktor migrasi juga tidak dipertimbangkan. Notasi laju kelahiran pada model (1) yang semula adalah $\mu$ diganti menjadi $\theta$ sehingga banyaknya kelahiran sebesar $\theta N$. Dengan demikian, individu $S$ bertambah sebesar $\theta N$. Di sini, diperhatikan kematian alami dan penyakit. Sama dengan model (1), laju kematian alami dinotasikan dengan $\mu$ sehingga banyaknya kematian pada individu $S, I$, dan $R$ berturut-turut sebesar $\mu S, \mu I$, dan $\mu R$. Dengan demikian, banyaknya individu $S, I$, dan $R$ berturut-turut berkurang sebesar $\mu S, \mu I$, dan $\mu R$. Jika $\delta$ adalah laju kematian karena penyakit maka banyaknya kematian karena penyakit pada individu kelompok $I$ sebesar $\delta I$. Dengan demikian, individu $I$ berkurang sebesar $\delta I$. Sama dengan asumsi model (1), pada penelitian ini, adanya kontak antara individu $I$ dan individu $S$, menyebabkan individu $S$ terinfeksi. Laju kontak dinotasikan dengan $\beta$ sehingga banyaknya individu $S$ dan $I$ berturut-turut bertambah dan berkurang sebesar $\beta \frac{S I}{N}$. Dengan demikian, model (1) berubah menjadi 


$$
\begin{aligned}
& \frac{d S}{d t}=\theta N-\beta \frac{S I}{N}-\mu S, \\
& \frac{d I}{d t}=\beta \frac{S I}{N}-\gamma I-\mu I-\delta I, \\
& \frac{d R}{d t}=\gamma I-\mu R .
\end{aligned}
$$

Vaksinasi dilakukan untuk mencegah penyebaran penyakit menular. Sama dengan Liu et.al. [5], di sini, individu $S$ yang telah divaksin dikategorikan sebagai individu $V$. Jika $\alpha$ adalah laju vaksinasi maka banyaknya individu $S$ yang divaksinasi sebesar $\alpha S$. Dengan demikian, individu $S$ berkurang sebesar $\alpha S$ dan individu $V$ bertambah sebesar $\alpha S$. Pada individu $V$ terdapat kematian alami sehingga banyaknya kematian alami pada individu $V$ sebesar $\mu V$. Dengan demikian, individu $V$ berkurang sebesar $\mu V$. Seiring berjalannya waktu, vaksin dapat kehilangan efektivitasnya dalam melindungi individu $V$ atau disebut masa berakhirnya imunitas vaksin. Oleh karena itu, sama dengan Naji dan Muhseen [6], pada penelitian ini, individu $V$ dapat kembali menjadi individu $S$. Jika $\lambda$ adalah masa berakhirnya imunitas vaksin maka banyaknya individu $V$ yang masa imunitasnya telah berakhir sebesar $\lambda V$. Dengan demikian, individu $V$ berkurang sebesar $\lambda V$ dan individu $S$ bertambah sebesar $\lambda V$. Oleh karena itu, model (2) berubah menjadi

$$
\begin{aligned}
& \frac{d S}{d t}=\theta N-\beta \frac{S I}{N}-\mu S-\alpha S+\lambda V, \\
& \frac{d V}{d t}=\alpha S-\lambda V-\mu V, \\
& \frac{d I}{d t}=\beta \frac{S I}{N}-\gamma I-\mu I-\delta I, \\
& \frac{d R}{d t}=\gamma I-\mu R .
\end{aligned}
$$

Berbeda dengan asumsi model (1) bahwa individu $I$ akan sembuh, di sini, sama dengan Side dkk. [9], individu $I$ harus melakukan pengobatan (treatment) atau digolongkan sebagai individu $T$ dahulu sebelum dinyatakan sembuh. Jika $k$ adalah laju pengobatan maka banyaknya individu $I$ yang melakukan pengobatan sebesar $k I$. Dengan demikian, individu $I$ berkurang sebesar $k I$ dan individu $T$ bertambah sebesar $k I$. Jika pengobatan berhasil maka individu $T$ dinyatakan sembuh. Notasi $\gamma$ pada model (1) yang semula adalah laju kesembuhan, di sini diubah menjadi laju keberhasilan pengobatan. Dengan demikian, banyaknya individu $T$ yang berhasil diobati sebanyak $\gamma T$. Dengan demikian, individu $T$ berkurang sebesar $\gamma T$ dan individu $R$ bertambah sebesar $\gamma T$. Saat menjalani pengobatan, dimungkinkan terjadi kematian alami sehingga banyaknya kemattian alami pada individu $T$ sebesar $\mu T$. Dengan demikian, individu $T$ berkurang sebesar $\mu T$. Oleh karena itu, model (3) berubah menjadi

$$
\begin{aligned}
& \frac{d S}{d t}=\theta N-\mu S-\beta \frac{S I}{N}-\alpha S+\lambda V, \\
& \frac{d V}{d t}=\alpha S-\lambda V-\mu V, \\
& \frac{d I}{d t}=\beta \frac{S I}{N}-\mu I-\delta I-k I, \\
& \frac{d T}{d t}=k I-\mu T-\gamma T, \\
& \frac{d R}{d t}=\gamma T-\mu R .
\end{aligned}
$$

Berbeda dengan asumsi model (1) yang individu sembuhnya memiliki kekebalan permanen, di sini, sama dengan Vargas [10], individu $R$ dimungkinkan kambuh menjadi individu $I$. Kekambuhan dapat terjadi karena adanya kuman yang tersisa dari infeksi sebelumnya yang berkembang kembali. Jika $\sigma$ adalah laju kekambuhan maka banyaknya kekambuhan pada individu $R$ sebesar $\sigma R$. Dengan demikian, individu $R$ berkurang sebesar $\sigma R$ dan individu $I$ bertambah sebesar $\sigma R$. Dinamika populasi model SVITR dengan kasus kambuh ditunjukkan pada Gambar 1. 


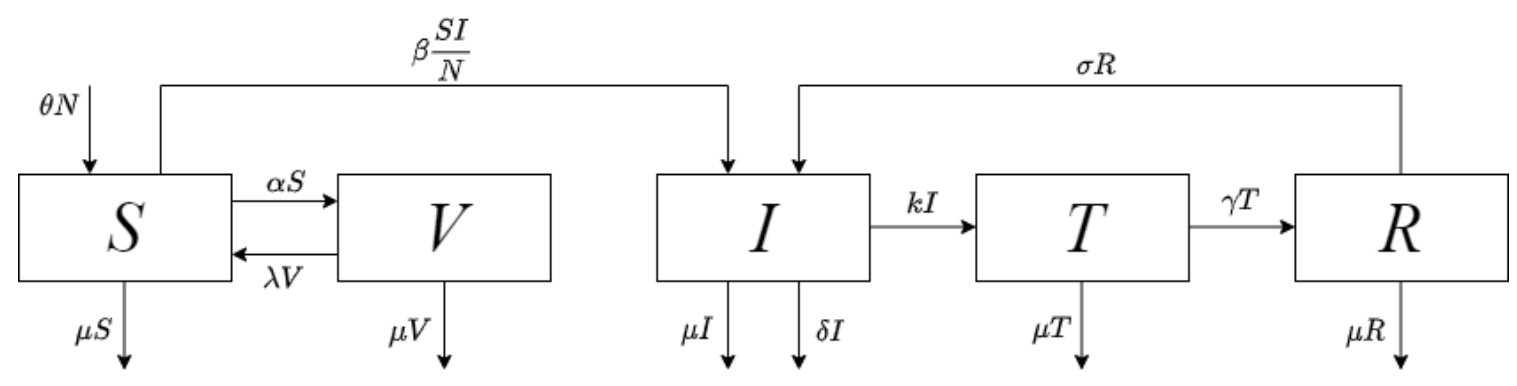

Gambar 1. Dinamika populasi model SVITR dengan kasus kambuh

Dengan demikian, model susceptible vaccinated infected treatment recovered (SVITR) dengan kasus kambuh ditulis sebagai

$$
\begin{aligned}
& \frac{d S}{d t}=\theta N-\mu S-\beta \frac{S I}{N}-\alpha S+\lambda V, \\
& \frac{d V}{d t}=\alpha S-\lambda V-\mu V, \\
& \frac{d I}{d t}=\beta \frac{S I}{N}-\mu I-\delta I-k I+\sigma R, \\
& \frac{d T}{d t}=k I-\mu T-\gamma T, \\
& \frac{d R}{d t}=\gamma T-\mu R-\sigma R,
\end{aligned}
$$

dengan $S(0) \geq 0, V(0) \geq 0 I(0)>0, T(0) \geq 0, R(0) \geq 0$, dan $\theta, \mu, \beta, \gamma, \alpha, \lambda, \delta, \sigma, k>0$. Sembilan parameter tersebut berturut-turut adalah laju kelahiran, laju kematian alami, laju kontak, laju keberhasilan pengobatan, laju vaksinasi, laju berakhirnya imunitas vaksin, laju kematian karena penyakit, laju kekambuhan, dan laju pengobatan. Model (5) adalah sistem persamaan diferensial nonlinear orde satu.

\subsection{Penerapan Model SVITR dengan Kasus Kambuh (Kasus Tuberkulosis di Indonesia)}

Model SVITR dengan kasus kambuh (5) diterapkan pada kasus TB di Indonesia. Data tahun 2004-2017 digunakan untuk mengestimasi nilai parameter sedangkan data tahun 2018 dan 2019 digunakan untuk mengukur keakuratan model. Hasil estimasi nilai parameter laju kelahiran $(\theta)$ sebesar 0.02066, laju kematian alami $(\mu)$ sebesar 0.00616 , laju kontak $(\beta)$ sebesar 1.00449, laju keberhasilan pengobatan $(\gamma)$ sebesar 0.54292 , laju vaksinasi $(\alpha)$ sebesar 0.02106 , laju berakhirnya imunitas vaksin $(\lambda)$ sebesar 0.06667 , laju kematian karena TB $(\delta)$ sebesar 0.33500, laju kekambuhan kekambuhan $(\sigma)$ sebesar 0.00495 , dan laju pengobatan $(k)$ sebesar 0.50435. Sembilan nilai parameter tersebut disubstitusikan pada model (5). Dengan demikian, model SVITR dengan kasus kambuh pada kasus TB di Indonesia dituliskan sebagai

$$
\begin{aligned}
& \frac{d S}{d t}=0.02066 N-0.02722 S-1.00449 \frac{S I}{N}+0.06667 V, \\
& \frac{d V}{d t}=0.02106 S-0.07283 V \\
& \frac{d I}{d t}=1.100449 \frac{S I}{N}-0.84551 I+0.00495 R, \\
& \frac{d T}{d t}=0.50435 I-0.54908 T, \\
& \frac{d R}{d t}=0.54292 T-0.01111 R,
\end{aligned}
$$

dengan $S(0) \geq 0, V(0) \geq 0 I(0)>0, T(0) \geq 0, R(0) \geq 0$.

Penyelesaian analitik model (6) sulit ditentukan. Oleh karena itu, digunakan metode numerik untuk menentukan penyelesaian pendekatannya. Metode yang digunakan adalah Runge-Kutta orde empat. Nilai awal yang digunakan mengacu data tahun 2004 yaitu

$$
\begin{aligned}
& S(0)=218345950, V(0)=4619722, I(0)=210229, \\
& T(0)=61316, R(0)=48459 .
\end{aligned}
$$


Selanjutnya, ditentukan penyelesaian model (6) dengan nilai awal (7) dalam periode 15 tahun pertama (2004-2019). Penyelesaiannya berupa banyaknya individu $S, V I, T$, dan $R$ pada tahun tersebut. Penyelesaian tahun ke 14 dan 15 dibandingkan dengan data tahun 2018 dan 2019. Diperoleh norm eror sebesar 0.71737. Oleh karena itu, model (6) cukup akurat dan dapat digunakan untuk memprediksi banyaknya individu $S, V I$, $T$, dan $R$. Penyelesaian model (6) dengan nilai awal (7) dalam periode 46 tahun pertama (2004-2019) direpresentasikan dengan grafik pada Gambar 1.

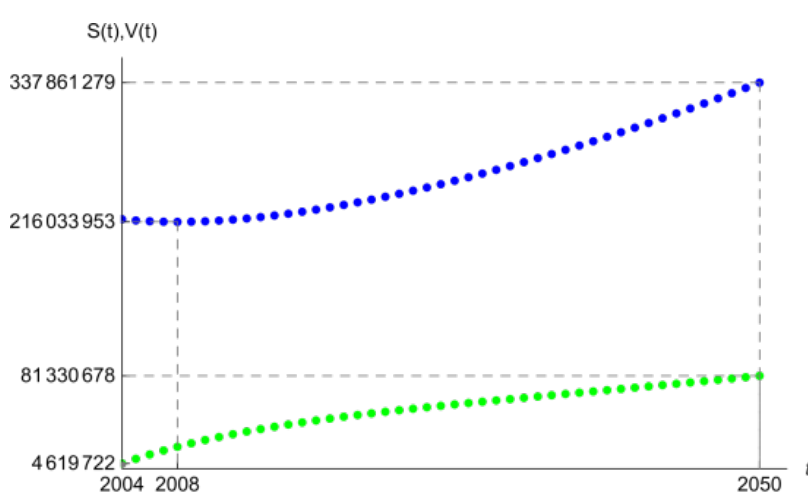

(a)

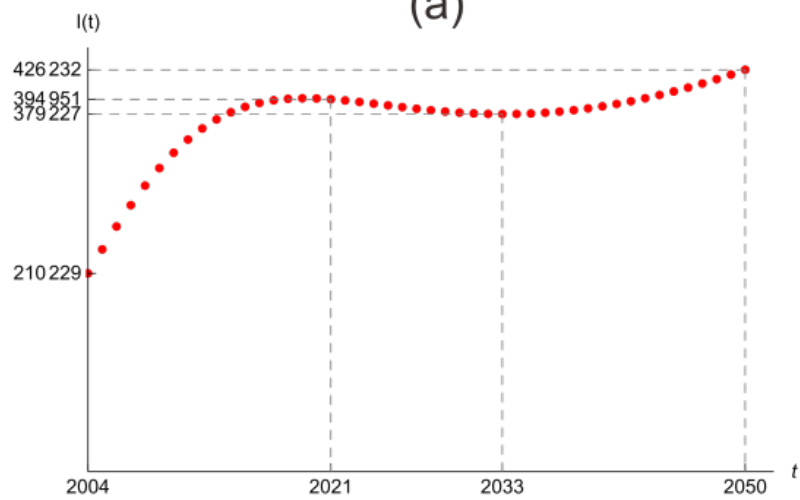

(c)

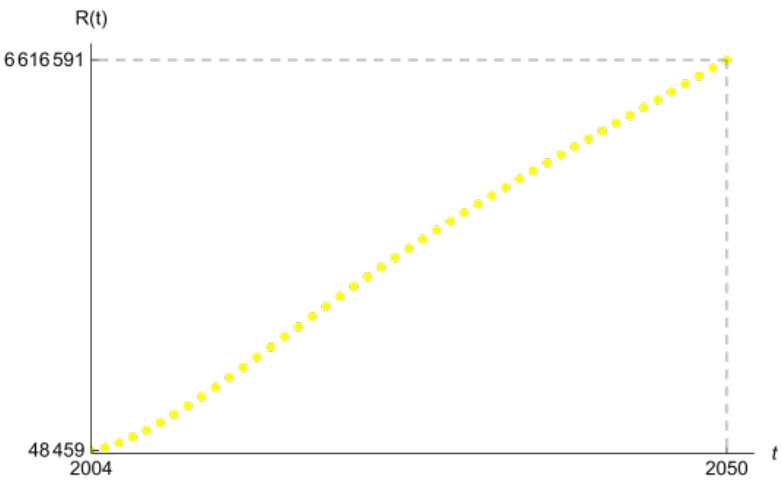

(b)

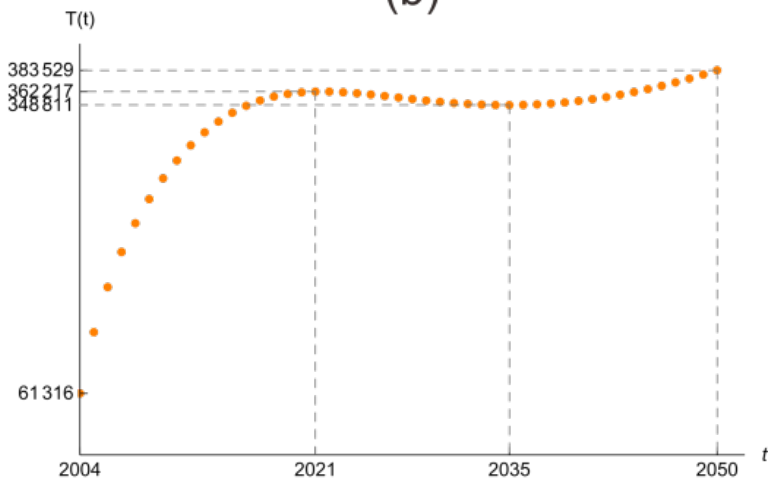

(d)

Gambar 1. (a) Banyaknya individu kelompok $S$ (biru) dan $V$ (hijau); (b) banyaknya individu kelompok $R$ (kuning); (c) banyaknya individu kelompok I (merah); (d) banyaknya individu kelompok $T$ (jingga).

Gambar 1 menunjukkan pola penyebaran tuberkulosis di Indonesia. Berdasarkan Gambar 1a, banyaknya individu $S$ mengalami penurunan pada empat tahun pertama (2008) kemudian mengalami peningkatan pada tahun-tahun berikutnya. Pada tahun 2050, banyaknya individu $S$ sebanyak 337861279 . Sedangkan individu $V$ mengalami peningkat setiap tahunnya dengan banyaknya individu $V$ pada tahun 2050 sebanyak 81330678 . Berdasarkan Gambar 1 b, banyaknya individu $R$ selalu mengalami peningkatan setiap tahunnya dengan banyaknya individu $R$ pada tahun 2050 sebanyak 6616591. Berdasarkan Gambar 1c, banyaknya individu $I$ mengalami kenaikan pada 17 tahun pertama (2021) dengan banyaknya individu $I$ pada tahun tersebut sebanyak 394951, kemudian mengalami penurunan hingga 12 tahun setelahnya (2033) dengan banyaknya individu $I$ pada tahun tersebut sebanyak 379327, dan mengalami peningkatan kembali pada 13 tahun berikutnya (2050) dengan banyaknya individu $I$ pada tahun tersebut sebanyak 426232. Berdasarkan Gambar 1d, banyaknya individu $T$ mengalami kenaikan pada 17 tahun pertama (2021) dengan banyaknya individu $T$ pada tahun tersebut sebanyak 362217, kemudian mengalami penurunan hingga 14 tahun setelahnya (2035) dengan banyaknya individu $T$ pada tahun tersebut sebanyak 348811 , dan mengalami peningkatan kembali pada 11 tahun berikutnya (2050) dengan banyaknya individu $T$ pada tahun tersebut sebanyak 383529. Berdasarkan Gambar 1, individu $S, V I, T$, dan $R$ mengalami trend naik. 


\subsection{Interpretasi dan Simulasi Hasil Penerapan Model SVITR dengan Kasus Kambuh (Kasus Tuberkulosis di Indonesia)}

Penerapan model SVITR dengan kasus kambuh pada kasus TB di Indonesia pada tahun 2004-2050 menunjukkan bahwa, individu sehat namun rentan terinfeksi TB mengalami penurunan hingga tahun 2008 kemudian mengalami peningkatan sampai tahun 2050. Individu yang divaksinasi BCG dan individu yang sembuh dari TB meningkat setiap tahunnya. Sedangkan individu yang terinfeksi TB, mengalami peningkatan hingga tahun 2021 kemudian mengalami penurunan hingga tahun 2033 dan mengalami peningkatan kembali hingga tahun 2050 serta masih terdapat 426232 individu yang terinfeksi TB. Individu yang melakukan pengobatan DOTS mengalami peningkatan hingga tahun 2021, kemudian mengalami penurunan hingga tahun 2035, dan mengalami peningkatan kembali hingga tahun 2050. Berdasarkan hasil tersebut, diprediksikan target bebas TB di Indonesia tahun 2050 belum tercapai.

Simulasi nilai parameter dilakukan untuk mengetahui langkah yang harus ditempuh untuk mencapai target bebas TB di Indonesia tahun 2050. Simulasi dilakukan dengan lima perlakuan, yaitu mengubah-ubah nilai parameter laju vaksinasi $(\alpha)$, laju $\operatorname{kontak}(\beta)$, laju pengobatan $(k)$, dan laju kekambuhan $(\sigma)$ sedangkan parameter lainnya tetap, serta mengubah-ubah empat nilai parameter tersebut sedangkan parameter lainnya tetap. Banyaknya individu $I$ hasil simulasi sampai tahun 2050 ditunjukkan pada Tabel 1 dan Tabel 2

Tabel 1. Banyaknya individu I hasil simulasi parameter $\alpha, \beta$, dan $k$

\begin{tabular}{cccccccccc}
\hline Tahun & \multicolumn{1}{c}{$\boldsymbol{\alpha}$} & \multicolumn{1}{c}{$\boldsymbol{\beta}$} & & & \multicolumn{1}{c}{$\boldsymbol{\mathbf { k }}$} \\
\hline $\mathbf{2 0 0 4}$ & 210229 & 210229 & 210229 & 210229 & 210229 & 210229 & 210229 & 210229 & 210229 \\
\hline $\mathbf{2 0 1 0}$ & 132469 & 13889 & 6761 & 3460 & 22439 & 191095 & 3652719 & 346930 & 35457 \\
\hline $\mathbf{2 0 2 0}$ & 16566 & 2603 & 1971 & 1409 & 4157 & 109064 & 45964137 & 420712 & 8518 \\
\hline $\mathbf{2 0 3 0}$ & 10775 & 2410 & 1823 & 1299 & 3643 & 72861 & 11078125 & 413934 & 7621 \\
\hline $\mathbf{2 0 4 0}$ & 10039 & 2235 & 1686 & 1200 & 3412 & 64465 & 3972345 & 425857 & 7395 \\
\hline $\mathbf{2 0 4 7}$ & 9697 & 2120 & 1596 & 1135 & 3273 & 64324 & 3582819 & 454410 & 7299 \\
\hline $\mathbf{2 0 5 0}$ & 9559 & 2073 & 1559 & 1109 & 3217 & 64858 & 3699367 & 471228 & 7265 \\
\hline
\end{tabular}

Tabel 2. Banyaknya individu I hasil simulasi parameter $\sigma$ dan gabungan $\alpha, \beta, k, \sigma$

\begin{tabular}{ccccccc}
\hline Tahun & & $\boldsymbol{\sigma}$ & & & $\boldsymbol{\alpha}, \boldsymbol{\beta}, \boldsymbol{k}, \boldsymbol{\sigma}$ & \\
\hline & & & & $\begin{array}{c}\boldsymbol{\alpha}=\mathbf{0 . 9} \\
\boldsymbol{\beta}=\mathbf{0 . 1} \\
\boldsymbol{k}=\mathbf{0 . 9}\end{array}$ & $\begin{array}{c}\boldsymbol{\alpha}=\mathbf{0 . 9} \\
\boldsymbol{\beta}=\mathbf{0 . 1} \\
\boldsymbol{k}=\mathbf{0 . 9}\end{array}$ & $\begin{array}{c}\boldsymbol{\alpha}=\mathbf{0 . 9} \\
\boldsymbol{\beta}=\mathbf{0 . 1} \\
\boldsymbol{k}=\mathbf{0 . 9}\end{array}$ \\
\hline $\mathbf{2 0 0 4}$ & 210229 & 210229 & 210229 & 210229 & 210229 & 210229 \\
\hline $\mathbf{2 0 1 0}$ & 328310 & 328364 & 328907 & 192 & 197 & 249 \\
\hline $\mathbf{2 0 2 0}$ & 319573 & 319987 & 324122 & 1 & 6 & 59 \\
\hline $\mathbf{2 0 3 0}$ & 209449 & 210342 & 219301 & 1 & 6 & 55 \\
\hline $\mathbf{2 0 4 0}$ & 121177 & 122475 & 135553 & 1 & 5 & 52 \\
\hline $\mathbf{2 0 4 7}$ & 80950 & 82464 & 97786 & 0 & 5 & 50 \\
\hline $\mathbf{2 0 5 0}$ & 68032 & 69623 & 85754 & 0 & 5 & 49 \\
\hline
\end{tabular}

Berdasarkan simulasi, jika penerima vaksin BCG ditingkatkan hingga 90\%, kontak antara individu rentan dengan penderita TB diturunkan hingga 10\%, cakupan pengobatan DOTS ditingkatkan hingga 90\%, dan kasus kambuh ditekan hingga $0.0003 \%$ maka diprediksikan target Indonesia bebas TB tahun 2050 dapat tercapai, bahkan sudah tercapai pada tahun 2047. 


\section{KESIMPULAN}

Model SVITR dengan kasus kambuh yaitu model (5). Model tersebut merupakan sistem persamaan diferensial nonlinear orde satu. Model SVITR dengan kasus kambuh pada kasus TB di Indonesia yaitu model (6). Pola penyebaran kasus TB di Indonesia menunjukkan bahwa pada tahun 2004-2050, individu sehat namun rentan terinfeksi $\mathrm{TB}$, individu yang divaksinasi $\mathrm{BCG}$, individu yang terinfeksi $\mathrm{TB}$, individu yang melakukan pengobatan DOTS, dan individu yang sembuh dari TB mengalami trend naik. Pada tahun 2050 masih terdapat 426232 penderita TB dan diprediksikan target bebas TB belum tercapai. Jika penerima vaksin BCG ditingkatkan hingga 90\%, kontak antara individu rentan dengan penderita TB diturunkan hingga 10\%, cakupan pengobatan DOTS ditingkatkan hingga 90\%, dan kasus kambuh ditekan hingga $0.0003 \%$ maka diprediksikan target Indonesia bebas TB tahun 2050 dapat tercapai.

\section{UCAPAN TERIMA KASIH}

Penelitian ini didanai oleh RKAT PTNBH Universitas Sebelas Maret TA 2021 melalui skema penelitian hibah grup riset (penelitian hgr-uns) dengan Nomor Kontrak: 260/UN27.22/HK.07.00/2021. Oleh karena itu, penulis dan tim riset mengucapkan terima kasih kepada pihak terkait atas dukungannya dalam pelaksanaan penelitian ini.

\section{DAFTAR PUSTAKA}

[1] CDC, "The Role of BCG Vaccine in the Prevention and Control of Tuberculosis in United State: A Joint Statement by the Advisory Council for the Elimination of Tuberculosis and the Advisory Committee on Immunization Pratices", MMWR, vol. 45, pp. 1-18, April 1996.

[2] Crofton, S., Crofton's Clinical Tuberculosis, Third edition. Oxford:Mcmillan Publishers Limited, 2009

[3] Hethcote, H. W., "The Mathematics of Infectious Disease”, Society for Industrial and Applied Mathematics, vol. 42, no. 4, pp. 599-653, 2000.

[4] Islam, S., "Equilibriums and Stability of SVIR Epidemic Model", International Journal of Humanities, Arts, Medicine and Sciences, vol. 3, pp. 1-10, January 2015.

[5] Liu, X., S. Iwami, and Y. Takeuchi, "SVIR Epidemic Models with Vaccination Strategies”, Journal of Theoretical Biology, 253, pp. 1-11, 2008.

[6] Naji, R. K. and A. A. Muhseen, "Stability Analysis Bifurcation of an SVIR Epidemic Model Involving Immigrants", Iraqi Journal of Science, 54, pp. 397-408, 2013.

[7] Pusdatin [Pusat Data dan Informasi], Profil Kesehatan Indonesia, Departemen Kesehatan Republik Indonesia, Jakarta, 20042019.

[8] Ramadhan, M. R., S. B. Waluya, dan M. Kharis, "Pemodelan Matematika Penyebaran Penyakit Tuberkulosis dengan Strategi DOTS", UNNES Journal of Mathematics, vol.7, no. 2, hal. 130-141, November 2018.

[9] Side, S., W. Sanusi, and N. F. Setiawan, "Analisis dan Simulasi Model SITR pada Penyebaran Penyakit Tuberkulosis di Kota Makassar", Jurnal Sainsmat, vol. V, no. 2, September 2016.

[10] Vargas-De-León, Cruz. "On the Global Stability of Infectious Diseases Models with Relapse”. Abstraction \& Application. 9 , pp. 50-61, 2013.

[11] WHO, Global Tuberculosis Report, WHO [Online]. Tersedia: https://www.who.int/teams/global-tuberculosis-programme/tbreports/global-report-2019 [Diakses: 2020]

[12] Widyaningsih, P., A. A. Nugroho, D. R. S. Saputro, and Sutanto, "Tuberculosis Transmission with Relapse in Indonesia: Susceptible Vaccinated Infected Recovered Model", Journal of Physics: Conference Series 1217 012071, pp.1-6, 2019.

[13] World Bank, "Birth and Death Rate, Crude, [Online]. Tersedia: https://data.worldbank.org/indicator/ SP.DYN.CBRT.IN dan https://data.worldbank.org/indicator/SP.DYN.CDRT.IN. [Diakses: 2020] 